\title{
New Patterns of Disclosure: How HIV-Positive Support Group Members from KwaZulu-Natal Speak of their Status in Oral Narratives
}

\author{
PHILIPPE DENIS* \\ University of KwaZulu-Natal, South Africa
}

\begin{abstract}
This paper examines the representations and emotions associated with disclosure and stigma in Pietermaritzburg, KwaZulu-Natal, seven years after the start of the South African government's ARV roll-out programme on the basis of in-depth oral history interviews of HIV-positive support group members. It argues that the wider availability of ARV treatment, the ensuing reduced fatality rate and the increased number of people, including men, who receive counselling and testing, may mean that HIV/AIDS is less stigmatised and that disclosure has become easier. This does not mean that stigma has disappeared and that the confusion created by competing world-views and belief systems has dissipated. Yet the situation of extreme denial and ideological confusion observed, for example, by Deborah Posel and her colleagues in 2003 and 2004 in the Mpumalanga province seems to have lessened. The interviews hint at the possibility that people living with HIV may have, more than a decade before, a language to express the emotions and feelings associated with HIV/AIDS. They were also found to be more assertive in matters of gender relations. These new attitudes would make disclosure easier and stigma more likely to recede.
\end{abstract}

Keywords: Disclosure, Gender, HIV/AIDS, KwaZulu-Natal, Oral History, Stigma

Three decades into the epidemic and nearly ten years after the start of the South African government's nationwide antiretroviral roll-out programme does HIV stigma, the single biggest obstacle to prevention, treatment and care, remain the same? Is it still as difficult for

* Email address for correspondence: denis@ukzn.ac.za.

Revised version of a paper read at the international conference on 'Biographies in Times of Crisis. Exploring Religious Narratives of AIDS in Africa and the African Diaspora' held on 13-15 December 2012 in Groningen under the auspices of the International Research Network Religious \& AIDS in Africa (IRNARA). I thank the anonymous reviewers as well as Julie Parle, my colleague at the University of KwaZulu-Natal, for their very helpful comments. 
people living with HIV to disclose their status to relatives, friends, fellow church members and colleagues? What do they say or refuse to say about themselves, their partners and their families when they speak of the disease? And in KwaZulu-Natal, where this study is located, what role does religion - mostly Christianity in its various forms and African traditional religion - play in the disclosure process? It is to these questions that this paper is devoted. Its ultimate aim is to contribute to a history of disclosure and stigma in the time of HIV/AIDS in South Africa. ${ }^{1}$

The main source of information is a set of oral history interviews conducted between July and December 2011 in the Pietermaritzburg area as part of the 'Memories of AIDS Project', a research programme of the Sinomlando Centre of the University of KwaZuluNatal supported by the National Research Foundation of South Africa (NRF) and the South Africa Netherlands research Programme on Alternatives in Development (SANPAD). For this particular paper ten interviews, with an accumulated recording time of twentytwo hours, were selected. ${ }^{2}$ All interviews were conducted by Ntokozo Zitha, a Zuluspeaking graduate of the University of KwaZulu-Natal. She made use of a topic guide designed by the research project's steering committee. Like the other fieldworkers, she was asked to engage the research participants on issues such as power, sexuality, gender, stigma, disclosure, religion, faith and community support. The author ran several training sessions for Ntokozo Zitha and the other fieldworkers. He discussed the content of the interviews with them with a view to their better understanding of the process at work in the interviews.

The two men and eight women who agreed to be interviewed belonged to Fountain of Life, ${ }^{3}$ a support group of people living with HIV established in Pietermaritzburg in 2003. A few support groups of this nature exist or have existed in the district but, unlike those described by Vinh-Kim Nguyen in West Africa in the 1990s for example, ${ }^{4}$ they tend to result from private initiatives, sometimes with the support of local churches. They only occasionally receive funding from international organisations, and public testimonials meant to raise awareness of HIV are rare. If South Africa AIDS organisations benefited from a massive injection of international funding in the aftermath of the 2000 Durban

\footnotetext{
${ }^{1}$ Peter Delius and Clive Glaser, charted the way in a suggestive essay: 'Sex, Disease and Stigma in South Africa: Historical Perspectives', African Journal of AIDS Research, 4 (2005), 20-36. See also Isak Niehaus, 'Death before Dying: Understanding AIDS Stigma in the South African Lowveld', Journal of Southern African Studies, 33 (2007), 845-60. For a historical perspective on the South African AIDS epidemic, see Howard Philips, 'AIDS in the Context of South Africa's Epidemic: Preliminary Historical Thought', South African Historical Journal, 45 (2001), 11-26; Didier Fassin, When Bodies Remember: Experiences and Politics of AIDS in South Africa (Berkeley, CA: University of California Press, 2007); Mark Hunter, Love in the Time of AIDS: Inequality, Gender and Rights in South Africa (Pietermaritzburg: University of KwaZulu-Natal Press, 2010). One of the most crucial aspects of the HIV/AIDS epidemic in African societies is the social response to death. See Rebekah Lee and Megan Vaughan, 'Death and Dying in the History of Africa since 1800', Journal of African History, 49 (2008), 345-49.

${ }^{2}$ During the first phase of the project (2008-10) 41 interviews of pastoral agents and NGO workers involved in the fight against HIV/AIDs in the Umgungundlovu District, KwaZulu-Natal, were conducted. During the second phase of the project (2011-13) a further 65 interviews and 11 focus group sessions were conducted. The audiorecordings, Zulu transcripts and English translations will be made accessible to researchers in the Alan Paton Centre, University of KwaZulu-Natal, Pietermaritzburg, in the course of 2014.

3 To respect the confidentiality of the testimonies, all names of persons as well as the name of the support group have been changed. The project received ethical clearance from the University of KwaZulu-Natal's Humanities and Social Sciences Research Ethics Committee.

${ }^{4}$ Vinh-Kim Nguyen, The Republic of Therapy: Triage and Sovereignty in West Africa's Time of AIDS (Durham, NC: Duke University Press, 2010).
} 
AIDS Conference, on the whole they are less dependent on external aid than those of other African countries. ${ }^{5}$

All members of Fountain of Life are HIV-positive. They meet once a month, usually on a Sunday, for lack of a better option, in a shop rented by one of them in town for business. They share stories and encourage each other to take their antiretroviral medication. Some go to clinics and hospitals to engage in HIV awareness. With the help of several faith-based non-governmental organisations (NGOs), the Pietermaritzburg Agency for Community Social Action (PACSA) in particular, they distribute food parcels and money for transport to their members. Fountain of Life is not supported by or affiliated to any particular church but the majority of its members, including Mary Khumalo, ${ }^{6}$ the founder, have strong Christian convictions.

The purpose of this paper is to examine the representations and emotions associated with disclosure and stigma in a particular place - the Pietermaritzburg area in KwaZulu-Natal at a particular time - 2011, seven years after the start of South African government's ARV rollout programme - on the basis of oral history interviews with members of HIV support group members. The first case of AIDS was diagnosed at Edendale Hospital, the biggest 'Black' hospital in the Natal Midlands, in 1987.7 In July 2004 Edendale Hospital became one of the first accredited facilities in KwaZulu-Natal for the Comprehensive Plan for Management, Care and Treatment for HIV and AIDS which included free ARV treatment for HIV patients with a CD4 count less than $350 .{ }^{8}$ From the beginning of the epidemic for various reasons, including a high number of migrant workers, KwaZulu-Natal has been and still is the South African province with the highest HIV prevalence.

\section{HIV Disclosure in the ARV Era}

While studies of disclosure, stigma and other HIV/AIDS-related social practices or discourses in South Africa are not rare, many questions remain unanswered and the responses given for one period are not necessarily valid five or ten years later. One of the first social scientists to study the social representations of HIV/AIDS in South Africa was Tessa Marcus, who conducted fifteen focus group discussions and ten indepth interviews on death and dying in the Pietermaritzburg area in $1999 .{ }^{9}$ Secrecy and stigma were mentioned in the study, but not disclosure, which did not attract attention at the time. In 2003 Seth Kalichman and Leickness Simbayi conducted a survey of attitudes to HIV testing and AIDS stigma among 224 men and 226 women in a black

\footnotetext{
5 The history of AIDS organisations in South Africa remains to be written. Some aspects of it are described in Steven Robins, 'From Rights to "Ritual”: AIDS Activism in South Africa', American Anthropologist, 108 (2006), 312-23; Katinka De Wet, 'Redefining Volunteerism: The Rhetoric of Community Home-Based Care in (the Not So New) South Africa', Community Development, 47 (2012), 111-25; Marian Burchardt, 'Access to the social: the ethics and pragmatics of HIV/AIDS support groups in South Africa', in M. Schlecker and F. Fleischer (eds), Ethnographies of Social Support. (Basingstoke: Palgrave Macmillan, 2013), 59-80. For a suggestive study of an AIDS support group in West Africa, see Kathryn Rhine, 'Support Groups, Marriage and the Management of Ambiguity among HIV-Positive Women in Northern Nigeria', Anthropological Quarterly, 82 (2009), 369-400.

${ }^{6}$ Not her real name. See footnote 3 above.

7 'Aids Suspect Has Blood Tested at Edendale Hospital', Witness Echo, 6 August 1987. On HIV/AIDS in Pietermaritzburg, see Julie Dyer, Health in Pietermaritzburg (1838-2008): A History of Urbanisation and Disease in an African City (Pietermaritzburg: Natal Society Foundation, 2012), 315-20.

8 Rob Stewart and Marian Loveday, 'The operational plan: Implementation of the antiretroviral therapy component', in South African Health Review (Durban: Health Systems Trust, 2005), 242.

9 Tessa Marcus, Wo! Zaphela Izingane - It is Destroying the Children: Living and Dying with AIDS (Pietermaritzburg: Children in Distress, 1999).
} 
township of the Western Cape. ${ }^{10}$ The same year Jonathan Stadler published the results of a research on secrecy and suspicion in relation to 47 AIDS-related deaths in a village of the Bushbuckridge district in the northern part of the Mpumalanga province. ${ }^{11}$

By the early 2000s, stigma, an obstacle to AIDS prevention, treatment and care identified since the mid-1980s, ${ }^{12}$ had become recognised by public health professionals as one of the major barriers to effective disease control. ${ }^{13}$ In $2002-3$ the World AIDS Campaign chose HIV/AIDS stigma and discrimination as a theme for the year, highlighting the importance the public health sector gave to stigma, both conceptually and programmatically. ${ }^{14}$ In June 2003 HIV/AIDS stigma featured prominently in the programme of the Sex and Secrecy Conference held at the University of Witwatersrand, Johannesburg, as shown in a special issue of the African Journal of AIDS Research on 'secrecy, stigma and HIV/AIDS'. ${ }^{15}$

While not focusing on stigma and disclosure in particular, the focus group-based survey Deborah Posel and her colleagues of the Wits Institute for Social and Economic Research (WISER) conducted in Agincourt, a densely populated area of rural Mpumalanga, in 2003 and 2004, provided rich insights into popular perceptions of death and HIV/AIDS-related disease which can usefully be compared to the data collected in 2011 in Pietermaritzburg, keeping in mind that the epidemic had started earlier in KwaZulu-Natal and that in this province the prevalence rates have always been higher than in the rest of the country. ${ }^{16}$ Also in 2003 and 2004, a research team led by Catherine Campbell conducted 120 interviews and focus groups on AIDS stigma in a peri-urban area near Durban and a deep rural area near Eshowe in KwaZulu-Natal. ${ }^{17}$ In 2004 the Durban-based Centre for the AIDS Programme of Research in South Africa (CAPRISA) conducted a household survey on stigma and discrimination in Inadi, another rural area in KwaZulu-Natal. ${ }^{18}$ The

\footnotetext{
${ }^{10}$ Seth Kalichman and Leickness Simbayi, 'HIV Testing Attitudes, Aids Stigma, and Voluntary HIV Counselling and Testing in a Black Township in Cape Town, South Africa', Sexually Transmitted Infections, 79 (2003), 442-7. In a further research project Kalichman and his colleagues studied discrimination experiences and internalised stigma in a group of 420 HIV positive men and 643 women in Cape Town. See L.C. Simbayi et al., 'Internalized AIDS Stigma, AIDS Discrimination, and Depression among Men and Women Living with HIV/AIDS, Cape Town, South Africa', Social Science \& Medicine, 64 (2007), 1823-31.

11 Jonathan Stadler, 'The Young, the Rich, and the Beautiful: Secrecy, Suspicion and Discourses of AIDS in the South African Lowveld', African Journal of AIDS Research, 2 (2003), 127-39.

12 As early as 1987, Jonathan Mann, the director of the World Health Organization's Global Programme on AIDS, was speaking of three epidemics: HIV infection, the AIDS epidemic itself and HIV/AIDS stigma, according to him the most explosive of the three. See Jo Stein, 'HIV/AIDS Stigma: The Latest Dirty Secret', African Journal of AIDS Research, 2 (2003), 95.

13 Stigma and AIDS in Africa: Setting an Operational Research Agenda, Dar es Salaam, Joint United Nations Programme on HIV/AIDS, 2001. See also HIV/AIDS Stigma and Discrimination: An Anthropological Approach: Proceedings of the Round Table held on 29 November at UNESCO-Paris. Studies and Reports, Special Series, Issue No 20. Division of Cultural Policies and Intercultural Dialogue, UNESCO, 2003.

14 Richard Parker and Peter Aggleton, 'HIV- and AIDS-related Stigma and Discrimination: A Conceptual Framework and Implications for Action', Social Science \& Medicine, 57 (2003), 13-14.

15 Graeme Reid and Liz Walker, 'Secrecy, Stigma and HIV/AIDS: An Introduction', African Journal of AIDS Research, 2 (2003), 85-8.

${ }^{16}$ Deborah Posel et al., 'Living with Death in a Time of AIDS: A Rural South African Case Study', Scandinavian Journal of Public Health, 35 (2007), 138-46.

${ }^{17}$ Catherine Campbell et al., 'I Have an Evil Child at My House: Stigma and HIV/AIDS Management in a South African Community', American Journal of Public Health, 95 (2005), 808-15; C. Campbell et al., 'Dying Twice: A Multi-Level Model of The Roots of AIDS Stigma in Two South African Communities', Journal of Health Psychology, 12 (2007), 403-7.

18 Lilian Mboyi et al., Understanding HIV and AIDS Stigma and Discrimination at a Community Level: Perspectives from Rural KwaZulu-Natal (Fitzroy, Victoria, Australia: Oxfam Australia, 2005).
} 
same year researchers from the Centre for the Study of AIDS, University of Pretoria, interviewed 140 community members on stigma in Hammanskraal and Temba, north of Pretoria. ${ }^{19}$ In 2006 a team of Human Science Research Council researchers led by Harriet Deacon published research on the nature and extent of HIV/AIDS-related stigma in the Anglican Church. ${ }^{20}$ In 2007 Isak Niehaus wrote a paper on death and stigma based on ethnographic research conducted in Bushbuckridge in northern Mpumalanga between 2003 and $2006 .^{21}$

As one can see, many studies on HIV/AIDS stigma in South Africa saw the light in the mid-2000s. With a paper on prevention, silence and denial in Venda, ${ }^{22}$ a doctoral dissertation in pastoral theology on HIV/AIDS silence ${ }^{23}$ and a contribution to an international project on HIV/AIDS and stigma, ${ }^{24}$ publications on disclosure and stigma in South Africa continued to appear in subsequent years, albeit at a slower pace.

The present study belongs to a different era of the South African HIV/AIDS epidemic. The current level of infection is still very high, but there has also been a significant drop in the number of AIDS-related deaths. Halfway through 2013, 2.1 million people were reported to be on antiretroviral treatment in South Africa. ${ }^{25}$ The country's life expectancy, which stood at 56.5 years in 2009 , had increased to 60 years two years later. With more than 13 million tests conducted over a period of fifteen months, the national HIV counselling and testing campaign launched by the South African government in April 2010 can be considered as a success. ${ }^{26}$

That migrant labour and other forms of social disruption brought about by colonialism and apartheid explain, at least in part, the severity of the South African HIV/AIDS epidemic, which tragically took its course as the country entered an era of democracy, is well established. ${ }^{27}$ There are reasons to believe that the culture of suspicion nurtured by apartheid and reinforced by political violence contributed to the aura of denial, which surrounded the HIV/AIDS epidemic in the early years. ${ }^{28}$ The infamous 'Mbeki controversy' with its questioning of the viral cause of AIDS, and, in the higher echelons of government of the usefulness of antiretroviral treatments, brought considerable confusion,

${ }^{19}$ Frans Viljoen (ed.), In Righting Stigma: Exploring a Rights-based Approach to Addressing Stigma (South Africa: AIDS and Human Rights Research Unit, University of Pretoria, 2005).

${ }^{20}$ H. Deacon et al., 'Breaking the Spirit of Fear: The Nature and Extent of HIV- and AIDS-Related Stigma in the Anglican Church of Southern Africa: A Quantitative Study', Report prepared by Human Sciences Research Council and Outsourced Insight for the Anglican Provincial AIDS Office, September 2006. http://www.hsrc.ac. za/Research_Publication-19916 (accessed on 19 January 2013).

${ }^{21}$ Niehaus, op. cit. (note 1).

22 Fraser G. McNeill, 'Condoms Cause AIDS: Poison, Prevention and Denial in Venda, South Africa', African Affairs, 108 (2009), 353-70.

${ }^{23}$ Benson Okyere-Manu, 'Engaging the Fertile Silence: Towards a Culturally Sensitive Model for Dealing with the HIV and AIDS Silence' (unpublished PhD dissertation, University of KwaZulu-Natal, 2008). The author conducted and transcribed 11 interviews of HIV support group members and caregivers in Pietermaritzburg and collected 29 responses to a questionnaire.

24 Maretha Visser and Heather Sipsma, 'The experience of HIV-related stigma in South Africa', in Pranee Liamputtong, Stigma, Discrimination and HIV/AIDS. A Cross-cultural Perspective (Dordrecht: Springer, 2013), 205-28. The study was conducted between 2003 and 2006 in two antenatal clinics of Pretoria.

${ }^{25}$ Andile Makholwa, 'HIV Infections Fall 30\% in Eastern and Southern Africa', Business Day, 30 July 2013.

26 Thobile Mbengashe et al., 'The National HIV Counselling and Testing Campaign and Treatment Expansion in South Africa: A Return on Investments in Combination Prevention', Poster Discussion Session, 19th International AIDS Conference, 22-7 July 2012, Washington DC, USA.

27 Simonne Horwitz, 'Migrancy and HIV/AIDS: A Historical Perspective', South African Historical Journal, 45 (2001), 103-23.

${ }^{28}$ Didier Fassin elaborates on this in When Bodies Remember: Politics and Experiences of AIDS in South Africa (Berkeley, CA: University of California Press, 2007). 
even though there is no evidence that it fostered denial and stigma at grassroots level. ${ }^{29}$ Then, in 2004, after a successful court case brought by civil organisations and a civil disobedience campaign, the South African government initiated an antiretroviral rollout programme which eventually became one of the most successful in the world. The interviews for this project bear no mark of a long-lasting effect of Mbeki's denialism among people affected or infected by HIV in Pietermaritzburg.

This article considers whether the wider availability of ARV treatment, the ensuing reduced fatality rate and the increased number of people, including men, who receive counselling and testing mean that HIV/AIDS is less stigmatised and that disclosure has become easier. If, as Niehaus suggested on the basis of testimonies collected in Bushbuckridge in the mid-2000s, ${ }^{30}$ the main reason for stigmatising, shaming or silencing the people suspected of being HIV-positive was the fear provoked by this disease's association with death, one should expect that the fear and the stigma related to it would decrease or even disappear when it becomes treatable and ceases to kill. Will this happen with HIV/AIDS in the ARV era as has been observed, to a certain degree at least, with cancer in the past few decades. And will the association of HIV/AIDS with immorality, stressed by other authors, also change? 'We believe', Campbell and her colleagues wrote in 2005, 'that even after the treatment is available and HIV/AIDS is no longer fatal, the link between HIV/AIDS and "bad behaviour" (i.e. sexual behaviour) will still exist in ways that associate the disease with shame and embarrassment'. ${ }^{31}$ Was this prediction correct? One of the questions the Memories of AIDS Project purports to address is whether or not stigma and discrimination are indeed abating in KwaZulu-Natal now that fewer people die of AIDS.

\section{Defining Disclosure and Stigma}

Before moving further we should clarify what we mean by disclosure and how oral history interviews relate to disclosure. We only speak here of voluntary disclosure: the lawful or unlawful disclosure by health care workers and other professionals of their clients' HIV status having to be considered separately. ${ }^{32}$ In the context of this study, disclosure means, first of all, disclosing one's HIV status to relatives, friends, colleagues or any other audience. The time between the discovery of the status and its disclosure and the number of people to whom disclosure is made varies from person to person. Some take years before disclosing their status to their mother, their sister or their best friend. Others speak to family and friends on the day of the test. A small number of people, very few in fact, disclose their status to public audiences, or even in the media.

In South Africa as in other African countries, being identified as HIV-positive is potentially dangerous. To avoid victimisation HIV-positive people carefully choose to whom they will disclose their status. ${ }^{33}$ Revealing one's HIV status at a workshop, in a support group or in public elicits solidarity and brings catharsis but it also gives rise to

\footnotetext{
${ }^{29}$ McNeill, op. cit. (note 22). On the politics of AIDS during this period, see Deborah Posel, 'Sex, Death and the Fate of the Nation: Reflections on the Politicization of Sexuality in Post-Apartheid South Africa', Africa, 75 (2005), 125-53; Nicoli Nattrass, Mortal Combat: AIDS Denialism and the Struggle for Antiretrovirals in South Africa (Pietermaritzburg: University of KwaZulu-Natal Press, 2007); Patrick Martin-Tuite, 'Whose Science? AIDS, History and Public Knowledge in South Africa', Intersect, 4 (2011), 8-25.

${ }^{30}$ Niehaus, op. cit. (note 1).

31 Campbell et al., 'I Have an Evil Child at My House', op. cit. (note 17), 814.

32 Viljoen, 'Disclosing in an age of AIDS: confidentiality and community in conflict', op. cit. (note 19), 65-93.

${ }^{33}$ Rhine, op. cit. (note 5), 391; Nguyen, op. cit. (note 4), 85.
} 
ambiguity, especially in contexts where displaying one's seropositivity is seen as a possible access to material resources. ${ }^{34} \mathrm{HIV}$ disclosure has been described as a 'technology of the self', in the sense in which Foucault uses this term, and like all technologies of the self it is performed in a complex web of power games. ${ }^{35}$

As suggested in the interviews, disclosure is an eminently gendered reality. In a groundbreaking study in the late 1990s, Susanne Leclerc-Madlala described how women tended to be 'demonised' in the context of HIV/AIDS. Her findings were that women were perceived as naturally 'dirty' and sexually 'out of control', and spontaneously blamed for the disease. ${ }^{36}$ The interviews showed that, more than ten years later, this perception still existed. Yet, women seemed to disclose their HIV status more willingly than men, presumably because it was more difficult for men than for women to admit to a medical condition that exposed their vulnerability. Likewise, it was easier for a woman to disclose her status to another woman than to a man since the man, for fear of having to take responsibility for the infection, tended to blame his female partner for it. In 2003 Simbayi and his colleagues found that the men they surveyed in Cape Town were more likely to have never discussed AIDs with friends and more likely to have been treated differently since testing HIV-positive than women in similar circumstances. ${ }^{37}$

The oral history interviews illustrate a second type of disclosure process. The narrators do not only speak of themselves - when I disclose my status - but of others - how the people I know disclose their status. The interviews, which form the basis of this study, document practices of disclosure - against a background of silence, denial, stigma and discrimination - in the interviewees' families, neighbourhoods, workplaces, churches and support groups.

But there is a third and equally significant level of disclosure: the sharing with the interviewer of new layers of feelings, emotions and experiences, some of them very intimate and never disclosed before. In an interview situation one does not normally disclose one's HIV status in the sense of revealing it for the first time to somebody. But that does not mean that there is no disclosure. Oral history is much more than the retrieval, by way of interviews, of factual information that cannot be found in written documents. It is, as seasoned oral history practitioners and theorists such as Ronald Grele, Alessandro Portelli, Paul Thompson and Alistair Thomson have pointed out, a complex interaction between an interviewer and an interviewee about events of the past, which require questioning, as well as listening, on the part of the interviewer. In a certain sense the interview situation creates the story. ${ }^{38}$ Ntokozo Zitha, the research assistant who

\footnotetext{
${ }^{34}$ Nguyen, op. cit. (note 4), 35-60; Robins, op. cit. (note 5), 316-18; Joan Comaroff, 'Beyond Bare Life: AIDS, (Bio)Politics and the Neoliberal Order', Public Culture, 19 (2007), 202-3.

35 Nguyen, op. cit. (note 4), 38-40. See Michel Foucault, 'Technologies of the self', in L.H. Martin et al. (eds), Technologies of the Self: A Seminar with Michel Foucault (Amherst: University of Massachusetts Press, 1988).

36 Suzanne Leclerc-Madlala, 'Demonizing Women in the Era of AIDS: An Analysis of the Gendered Construction of HIV/AIDS in KwaZulu-Natal', (unpublished PhD thesis, University of Natal, 1999).

37 Simbayi et al., 'Internalized AIDS stigma', op. cit. (note 10), 1829.

38 See Ronald Grele, 'Movement without aim: methodological and theoretical problems in oral history', in Ronald Grele (ed.), Envelopes of Sound: The Art of Oral History (New York: Praeger, 1999); Alessandro Portelli, The Death of Luigi Trastelli and Other Stories: Form and Meaning in Oral History (Albany, NY: State University of New York Press, 1991); Paul Thompson, The Voice of the Past: Oral History (New York: Oxford University Press, 2000); Alistair Thomson, 'Memory and remembering in oral history', in Donald Ritchie (ed.), The Oxford Handbook of Oral History (New York: Oxford University Press, 1999), 77-95. On the practice of oral history in the South African context, see Philippe Denis, introduction in Philippe Denis and Radikobo Ntsimane (eds), Oral History in a Wounded Country: Interactive Interviewing in South Africa (Pietermaritzburg: University of KwaZulu-Natal Press, 2008), 1-21.
} 
conducted the interviews discussed in this paper, reported that, several times, the Fountain of Life support group members she interviewed said that they were sharing aspects of their lives that they had not mentioned to other people before: 'It is easy to talk to you,' they would confide at the end of the interview. 'I do not know why I am speaking to you like this. I say things I have never said before.' ${ }^{39}$ 'For some crazy reason I talk stuff I have never spoken about to some audiences. ${ }^{40}$ 'Normally I do not talk about this but somehow I trusted you. ${ }^{41}$

If people who test HIV-positive or suspect that they have contracted the virus find it so difficult to disclose their status it is likely because they are terrified at the idea of being rejected or victimised by family members, friends and colleagues. ${ }^{42}$ The list of medical conditions and life situations which attract stigma - cancer, tuberculosis, mental or physical disability, homosexuality, single motherhood, imprisonment, to name a few - is long. Yet, few diseases in history have been as much stigmatised as HIV/AIDS, making it extremely difficult to be talked about and owned up to. The link between sex, sin and immorality often made by Christian ministers and preachers and internalised by large sectors of the African community has added to the stigma. ${ }^{43}$ As a result many HIV-positive people do not go for testing or, if they do, they do not collect their results and do not seek treatment. Stories of people who preferred to die rather than being seen as carriers of the virus have been documented. ${ }^{44}$

But what is stigma? The first generation of AIDS health professionals, activists and researchers envisaged stigma, in the terms of Erving Goffmann, the author of an influential book on this theme, as 'an attribute that makes [someone] different from others ... and of a less-desirable kind' ${ }^{45}$ The problem with this definition of stigma was that it was seen as a static characteristic of the person. It was a 'kind of thing' attached to the person which 'spoiled' his or her identity. The best strategy to defeat stigma, it was felt, was to disseminate information and encourage a change of attitude in the population confronted with the stigmatised difference. To this individual approach regarding stigma, Richard Parker and Peter Aggleton have opposed a more social one. For these scholars stigma is a process during which social actors seek to legitimate their status within existing

\footnotetext{
${ }^{39}$ Notes from a report-back session, 7 November 2012.

${ }^{40}$ Interview conducted by Ntokozo Zitha on 5 December 2011 in Pietermaritzburg.

${ }^{41}$ Interview conducted by Ntokozo Zitha on 11 December 2011 in Pietermaritzburg.

42 On the difficulty of disclosing one's HIV status in South Africa, see Radikobo Ntsimane, 'To Disclose or not to Disclose: An Appraisal of the Memory Box Project as a Safe Space for Disclosure of HIV Positive Status', Journal of Theology for Southern Africa, 125 (2006), 7-20.

${ }^{43}$ Campbell et al., 'I have an Evil Child at My House', op. cit. (note 17), 810. There is a growing body of literature on HIV/AIDS, religion and theology in Africa. For an overview, see Beverley Haddad (ed.), Religion and HIV and AIDS: Charting the Terrain (Pietermaritzburg: University of KwaZulu-Natal Press, 2011). On the Christian churches' response to HIV/AIDS in South Africa, see Mark Krakauer, 'Churches' Responses to HIV/AIDS in Two South African Communities', Journal of the International Association of Physicians in AIDS Care, 6 (2007), 27-35; Philippe Denis, 'The Church's Impact on HIV/AIDS Prevention and Mitigation in South Africa', Journal of Theology for Southern Africa, 134 (July 2009), 66-81. For a bibliographical survey on religion, HIV/AIDS and stigma see Gillian Paterson, 'HIV, AIDS and stigma: discerning the silences', in Haddad, Religion and HIV and AIDS, 350-65.

44 Jonny Steinberg, Three Letter Plague: A Young Man's Journey Through a Great Epidemic (Johannesburg: Jonathan Ball Publishers, 2008).

45 Erwing Goffmann, Stigma: Notes on the Management of Spoiled Identity (New York: Simon and Schuster, 1963), 3. For a discussion of the literature on stigma see Bruce Link and Jo Phelan, 'Conceptualizing Stigma', Annual Review of Sociology, 27 (2001), 363-85; Anish Mahajan et al., 'Stigma in the HIV/AIDS Epidemic: A Review of the Literature and Recommendations for the Way Forward', AIDS, 22 (2008), 567-79.
} 
structures of inequality by devaluating others. ${ }^{46}$ It is a matter of social control. As we shall see, the constant reference to male domination in the narratives of (female) Fountain of Life support group members resonates with this view. But as Harriet Deacon suggests, Parker and Aggleton's approach is also too rigid. Stigma is not only about power and social control, it is also about fear and insecurity. Using Hélène Joffe's work on risk and the 'other' ${ }^{47}$ : Deacon defines stigma as an emotional process in which people distance themselves from risk by projecting it onto 'outgroups'. They gain an illusion of control by the attribution of risk-enhancing behaviour to the 'other', blaming 'outgroups' for being at risk. ${ }^{48}$ In this paper we shall combine the two approaches as there is an interplay between social and emotional factors. It is true that people are afraid of disclosing their HIV status because of the weakness of their social and cultural position. They do not feel strong enough to risk the enmity of those they believe have power over them. But social power does not necessarily mean emotional power. The stigmatisers are no less vulnerable than the stigmatised. Emotionally, if not socially - often both, in fact - they are also in a weak position because of their fear of the disease and their inability to deal with the emotions attached to it.

\section{Indicators of Change}

The present study is based on the assumption that, while continuing in new forms, the difficulty for HIV-positive people to disclose their status and the reality of stigma may change over time, especially in view of the longer life expectancy brought about by the wide availability of ARV treatment. To assess the change in the narratives of Fountain of Life support group members we shall use an adapted version of the typology of the roots of stigma proposed by Catherine Campbell and her colleagues on the basis of the survey they conducted in two areas of KwaZulu-Natal. ${ }^{49}$ These authors are familiar with the debate on the nature and causes of stigma referred to above.

HIV stigma and discrimination ${ }^{50}$ - and the ensuing reluctance to disclose one's status can stem from one or more of the following six causes:

- Lack of information;

- Confusion caused by the availability of competing beliefs systems;

- Fear of death;

- Shame provoked by the association of HIV with sex;

- Feeling of helplessness and insecurity (especially among males);

- Lack of social spaces to talk about HIV/AIDS.

\footnotetext{
${ }^{46}$ Parker and Aggleton, op. cit. (note 14), 14.

47 Hélène Joffe, Risk and the 'Other' (Cambridge: Cambridge University Press, 1999). On othering and stigmatisation, see also Link and Phelan, op. cit. (note 45), 370; Campbell et al., 'I Have an Evil Child in My House', op. cit. (note 17), 808.

48 Harriet Deacon, Understanding HIV/AIDS stigma: A theoretical and methodological analysis (Cape Town: Human Sciences Research Council, 2005), 18.

49 Campbell et al., 'Dying twice', op. cit. (note 17).

50 I do not enter here into the debate of whether stigma, a belief and an ideology, and discrimination, a social practice, are two separate realities (Deacon) or if they are integrated, discrimination being the necessary consequence of stigma (Campbell et al., 'Dying twice').
} 
The first two are related. As Delius and Glaser suggested and Posel's Agincourt study confirmed, in the early 2000s the western-based biomedical approach, which defined AIDS as a deficiency of the immune system caused by a virus called HIV, and the traditional belief systems, which explained the phenomenon of multiple deaths as the result of a lack of harmony between the living and the dead due, among other reasons, to the transgression of cultural taboos, were in open competition, creating conditions for confusion, silence and denial. To this we could add that the 'healing churches' represent a third kind of belief system: for them it is God who heals AIDS when the right prayers are addressed to him, and not western medicine. ${ }^{51}$ We should ask ourselves if, in a country like South Africa, this situation of ideological competition is as prevalent in the early to mid-2010s as it was a decade earlier. The interviews seem to indicate that the biomedical message - HIV is a virus and the ARV treatment does work - is more widely accepted that it has ever been.

The next three factors - fear of death, shame and helplessness - all belong to the realm of emotions. They are notoriously difficult to assess but they are nevertheless historically significant. ${ }^{52}$ This paper will discuss them in relation to the ten interviews of HIV/AIDs support group members in Pietermaritzburg. It must be kept in mind that, as HIV increasingly becomes a treatable disease, the image of death is less likely to contribute to stigma, at least directly.

The last factor is more tangible, though difficult to ascertain with precision given the variety of life situations with which people living with HIV are confronted. One way of assessing the amount of social space to talk about HIV/AIDS is to examine the number and longevity of HIV/AIDS support groups in contexts where one-to-one counselling is hard to find and perhaps not culturally appropriate. As mentioned before, in this study we shall also consider the interview as a space for engagement with HIV/AIDS and disclosure.

\section{Profile of the Interviewees}

The eight women and two men whose oral testimonies are analysed here were identified by the snow-ball method. The first one - Mary Khumalo, the founder of Fountain of Life - was introduced to the research assistant by a member of the research steering committee. During the interview she mentioned other names of support group members who themselves suggested more names. The sample constituted in this way was fairly homogenous in terms of generation - all but two were in their forties (born between 1964 and 1971) - and heterogenous in terms of race, gender, socio-economic status and living conditions. Three had a well-remunerated job; one worked as a hair dresser; the others were unemployed. Two lived in the central district of Pietermaritzburg, six in neighbouring townships and two in a semi-rural area at some distance from the city. Neither of the two men was isiZulu-speaking: one was a foreigner and the other a white South African. One of the women was an eastern African national married to a Zulu man; the other seven were Zulu women. Out of the six who had been married, five had lost his or her partner to AIDS. Four had never been married but had children. The majority had been diagnosed HIV-positive in the late 1990s or early 2000s. Some had joined Fountain of Life at its inception, others in subsequent years.

${ }^{51}$ For a discussion of the relationship between biomedicine, Christianity and African belief systems in matters of health, see Toyin Falola and Matthew Heaton (eds), Health Knowledge and Belief Systems in Africa (Durham, NC: Carolina Academic Press, 2008), xxii-xxiv.

${ }^{52}$ I owe this insight to a conversation with my colleague, the historian Julie Parle, who is currently working on a project of the history of emotions and mental illness in KwaZulu-Natal in the 1800s and early 1900s. 
The interviewees were also different in terms of religious affiliation. All were confessed Christians but only eight were regular churchgoers. Three belonged to mainline churches (Methodist, Dutch Reformed and Seventh-day Adventist), four to Pentecostal churches (the Oasis of Workshop Tabernacle, the Pietermaritzburg Christian Fellowship and an unspecified Pentecostal church) and the remaining four to African independent churches (St John's Apostolic Faith Mission, Christian Catholic Apostolic Holy Spirit Church in Zion and Twelve Apostles Church in Zion). Of those who worshipped in a Pentecostal church two were from a Catholic background. One moved from one Pentecostal church to another.

\section{The Disclosure Experience}

All the interviewees had a clear memory of the day they disclosed their HIV status to relatives or friends for the first time. For some, as we shall see later, the narration of what happened on that day was a key moment in the interview. The interviews also indicate to whom the interviewees did not disclose their status for reasons that we shall have to examine.

Mary Khumalo's story is particularly striking. While still a young girl in Kenya, she was raped by an Umkhonto weSizwe cadre, ${ }^{53}$ whom she agreed to marry to avoid embarrassment. As one could expect it was not a happy marriage. In South Africa where she followed her husband in the early 1900s she discovered she was HIV-positive after he had fallen sick. An ANC activist, who later became a prominent politician, helped her to come to terms with her situation as a HIV-positive person. When her husband died, the other members of the family were in denial:

My mother-in-law said: 'No, it must be the apartheid government. They must have poisoned him.' And it was easy to believe that because a lot of men who were coming from exile were dying of AIDS. So what explanation would make sense to this elderly woman? South Africa had been totally protected from HIV because of the apartheid era. It was a disease out there. But also the denial of 'My child cannot be having. . '. The more sensible and acceptable thing was that De Klerk and Verwoerd had poisoned them as there were crossing the border coming back here..$^{54}$

Only later had they been able to talk. At first her sister-in-law was angry at her. The family was in denial. Before her husband died the family had wanted her to call a pastor, but she did not. She later regretted it.

Beatrice, who replaced Mary Khumalo as leader of Fountain of Life after she had left the organisation in 2010 for health reasons, disclosed her status to the members of her family on the day she came back from the hospital in 2003. But, she continued, there were some people who would react unsympathetically if she disclosed her HIV status to them:

First it was my children, and then my husband, and the same day my mother. All of them I sat them down when I came back from the hospital. I sat them down like this. I told them. And this one is crying this side, this one... I stood up and went to the bedroom. And then from there I started telling the people who I knew were close to me. There are some who I knew even up to now.... Some people don't know about my status because I knew that it's like. .. . They are not somebody . . . because they were talking badly and I would get hurt. I get hurt. So there are some it's just that I can tell and, you know, somebody who is going to rub you on the shoulder. It's going to be okay. But some eh... eh. . you just look and say this one....

Nonhlanhla, who got married to her husband in 2001 after having cohabited with him for fifteen years and then lost him to AIDS two years later, faced denial when she revealed

\footnotetext{
${ }^{53}$ Umkhonto weSizwe (MK) was the armed wing of the African National Congress when this movement was banned by the apartheid government (1960-90).

${ }^{54}$ For similar stories, see Campbell et al., 'I Have an Evil Child at My House', op. cit. (note 17), 811. Some of the informants referred to the spread of HIV/AIDS as the white regime's last attempt to undermine black opposition.
} 
her own status to him. 'You look so well, he answered, that there is no need to check.' When her mother learned about her condition, she was so shocked that she had a heart attack. Her sisters also reacted negatively.

Things went better with Thandeka who became HIV-positive around 1997 but waited until 2008 before talking to her family. They took it very well. She felt free to disclose her status to women, not to men.

For Nonhlanhla also being HIV-positive was emotional. Abandoned by her mother and raised by her grandfather, she fell pregnant at the age of nineteen. When she heard that she was HIV-positive in 2004, she cried a lot, but her children responded well. They only cried because she was crying:

They did not cry about it. The reason they cried was because I cried, because I felt the pain of what I was telling them. They didn't cry because I was HIV-positive but they cried because they saw my tears. But it didn't last long. It just took a few minutes and then we comforted each other. They accepted it they do not have a problem. They even sometimes make a joke out of it.

As for Nomfundo, she spoke to her family when she heard that she was HIV-positive in 2000, but she did not tell her son, aged ten at the time. She let him discover it by himself, she explained in the interview. Now she was afraid to disclose her status to her second child, a 15-year-old daughter.

With Nozipho the problem was not the child but the husband. Her sister-in law reacted positively when she told her that she had tested positive in 2001 but she advised her not to say anything to her brother - Nozipho's husband - because he would 'kill' her. Overall the family responded well and her siblings went for a test after her.

The easiest disclosure experience was that of Nokwazi. She discovered her status in 2010 and told everybody at home on the same day, apparently without any problem. But, perhaps significantly, her disclosure happened much later than had been so with the other interviewees, at a time when the ARV treatment was widely available. This may explain why the disclosure process went on so smoothly.

We leave the two men to the end. George, an East African who arrived in Pietermaritzburg in 2005, had been on ARVs since 2001. He went for a test after his wife had been identified as positive. He reported that his friends and his new girlfriend were very supportive even though he did not feel free to disclose his status to everybody. Godfrey, a white man who had worked in Zimbabwe and by the time of the interview was employed by a media company in Pietermaritzburg, experienced discrimination in his home town in the North-West province. He disclosed his HIV status to his boss out of a sense of responsibility, but not to his fellow workers because he felt he could not trust them.

This brief survey shows that all the interviewees revealed their HIV status to some family members or some friends. Some faced denial and rejection. Three of the eight women interviewed explicitly mentioned difficulties with men, be it their husband, their in-laws or men in general. One admitted to having failed to disclose her status to her children. Another one waited several years before disclosing her status to her family. Most first disclosures were made in the early 2000s. The one which took place a decade later was experienced as being easier than the others.

\section{Women as Vessels}

The interviewees did not only speak about their experience of disclosure but that of others. This led them to articulate, in response to the questions of the fieldworker, personal thoughts on stigma, gender relations and pastoral attitudes. 
For Mary Khumalo, attitudes have changed. There is less stigma than before. She credited herself and other AIDS activists for the evolution of attitudes:

We have achieved much [...], making it to the network. I think part of what we have really achieved is breaking the stigma because, I remember, when I started to open up about my HIV status in Imbali, there was so much silence and it took years. So when I started Fountain of Life I had a few people but people now just stream [in] every day. I have no peace.

But in her opinion the change has been only partial. In the last part of the interview she stressed that it is only women who have started adopting more open attitude. Fountain of Life worked mostly with females and many of them were single mothers. Men, she interjected, were just 'good to abuse women':

We spoil men. You will get a man sitting at home, driving the car. The woman is the one working hard to buy that car. He will use that car to go and have affairs, come back and beat her, you know. So you set an environment for you to be abused. You have children with this man who never marries you and who go and pay lobola (bridewealth) somewhere else and ask something simple like ... I know the Zulu values, the lobola culture.

In the interview Mary used the phrase 'sleep around' several times. To her the association between HIV and promiscuity was evident, even though her life story proved the opposite. 'I grew up', she explained, 'knowing that I would never be HIV-positive because I behaved well. I was not sleeping around.'

Mary's interview confirmed the existence of the stereotype of the loose woman who spreads the virus. For her disclosing one's status was 'very easy', but it depended on to whom. In her experience, men were not prepared to disclose. Very few of them went for testing and if they tested positive they blamed the women: 'They say it is because of you. You come and infect me. Men always like to blame women. There are very few of them who understand. [... ] If a man could understand that HIV is just like sugar [diabetes] or salt [high blood pressure].'

Asked why some women kept their status secret, she answered that the fear of being blamed for the infection prevented them from being open about it:

As I told you, people keep (their status) secret. Let us say I have a boyfriend in Dambuza and this boyfriend in Dambuza has died of AIDS. If I disclose my status and another boyfriend in Sobantu has died and another one in Imbali, ${ }^{55}$ all from the same disease. If I disclose, if I tell the community about my status, they will think that is me who has infected their son. They will not think it is their son who has infected me. As a woman I am like a vessel. Whatever comes to me I am like a container. I am collecting from Sbu and then I am collecting from Bongani. I am collecting. ... I keep collecting, collecting, collecting.

The gendered nature of the response to the epidemic also came through in Thandeka's interview. Like the other women she noted the association of HIV/AIDS with 'bad behaviour'. Men did not want to take responsibility for it. If they knew they were HIVpositive, they refused to tell their partners.

Sometimes the man does not want to use a condom. He knows that he has the virus but he does not tell his partner and keeps it secret. I wonder then how this man will take the [ARV] treatment because you can find that we live together. Then where does he hides his treatment, I don't know. He does not tell the woman while the woman tells him.

If the man refused to be open about his status, the woman remained silent as well, afraid of being abandoned by her partner. Thandeka's job as a Fountain of Life volunteer was to convince HIV-positive women of the necessity of telling the truth. 'I tell the person and

55 Dambuza, Sobantu and Imbali, three 'townships' of Pietermaritzburg classified as black under apartheid and still predominantly inhabited by black people, are situated at a short distance from each other. 
then it will be up to the person to decide. You cannot force somebody to love you when you tell him about your status.'

This is exactly what happened to Nonhlanhla. Both her husband and a boyfriend refused to be open about their status. She broke up with them. To her dismay she found the same attitude in her church. Her pastor did not allow her to speak to the congregation about HIV/AIDS and to promote condoms. As we shall see in the next section, this response infuriated her.

The reluctance of church people to face the reality of HIV/AIDS is another common theme in the interviews. Beatrice, the new coordinator of Fountain of Life, spoke about this at some length. Her pastor had allowed her to speak to the congregation, she explained, but the sentiment continued to prevail among the worshippers that people living with HIV were people who 'sleep around':

We have been trying to engage with churches because... eh. . . in the churches.... They do not want to talk about HIV/AIDS. I am so thankful because my pastor is somebody with whom I have been able to sit down. ... I told him about my experience and he is very open about it since. Like now, we are trying to open a desk in the church. It is because a lot of people in the church are dying. It is because they cannot talk. It is because, when they find that somebody is HIV-positive, they say he has been sleeping around. It is not that this person has been sleeping around to be infected. There are many ways for a person to be affected by the virus.

The problem, according to her, was that the people in the church 'always judge', especially if they are 'born again': 'We always judge ourselves. This one is a born again. What happened? You see. This is the message we try to bring to the churches. And it is not only my church. I want to go to the other churches as well.'

George had the same experience. In his church nobody said anything about HIV/AIDS because they were not able to face the reality of the disease: 'Some people in the church, when they get to hear that somebody is HIV-positive, it is really as if he is about to die, you know. Maybe by sitting next to them they are going to get it, you know. They do not really understand that the church is more kinda like. ... You understand what I am saying.'

Reading these interviews, one cannot help being struck by the persistence of antagonistic gender representations, in all contexts including the church. All the women interviewed spoke of male dominance and poor communication between genders on intimate matters. When reference was made to 'African culture', it was in relation to gender patterns and sexual roles assumed to be traditional in African society, ${ }^{56}$ rather than to the function played by ancestors and other spiritual forces in the world of the living and to the rituals and cultural observances required to maintain harmony in the community. It was as if 'African culture' was only about the domination of women by men.

\section{The Interview as a Space for Disclosure}

The interviews, this paper argues, do not only provide information about HIV disclosure, they also create the conditions for disclosure. The fact that the Fountain of Life support group members interviewed for this project were prepared to disclose sensitive, emotional and painful aspects of their experiences as people living with HIV/AIDS in an oral history interview situation is significant. It indicates that, as least for them, such an experience can be shared and that a language exists in which to express it.

${ }^{56}$ Peter Delius and Clive Glaser, 'Sexual socialisation in South Africa: A Historical Perspective', African Studies, 61 (2002), 27-54. 
HIV disclosure is not, as is often believed, a once-off phenomenon. It is a process evolving over time. One can be open about one's status at first, then more restrictive because of a bad experience or the opposite. One can disclose some aspects of one's HIV condition, but not all. One can speak of HIV in general to some people and with more details to others. One can disclose one's HIV status only to some family members or only to the members of one's support group. One hears of people who disclose their HIV status to public audiences, but are unable to do the same with family members. In short, there are many layers of disclosure. It is like peeling an onion. The most difficult part to disclose is the circumstances of the infection because, in most cases, it relates to a sexual experience.

None of the ten interviewees disclosed their status for the first time during the interview. They had revealed it before to family members, not to mention the members of their support group. Yet, aspects of their experiences that had not been disclosed to friends and relatives sometimes came out in the interview because of the particular character of this encounter. As noted before, many of the interviewees admitted to having said to the interviewer things they had never spoken about before.

Mary's story illustrates this. Active in the NGO sector for many years and used to talking about her HIV status in public, she had never revealed to the people who knew her well the conditions of her marriage - a union contracted after a rape to avoid embarrassment and the cloud this painful experience cast on her HIV infection. She did not manifest any emotion during the interview as if her story were just a matter of fact, but several aspects of her biography, particularly the decision to entrust the care of her child to a relative in the United States of America, revealed high levels of pain and distress. She managed to hide her sentiments. Only in the last part of the interview, when she explained her decision to leave the organisation she had founded so as to avoid a further deterioration of her mental health through excessive stress, she expressed painful feelings. In the end, her interview shows a degree of agency and resilience rarely noted in the literature on HIV/AIDS in South Africa. 57

Talking about one's HIV status is never easy. Thandeka cried at the beginning of the interview before agreeing to continue. Aware of her HIV status since 1997 she had waited until 2008 before revealing it to her family. She did not elaborate in the interview on why she waited so long. Since she was at pains to explain that neither God nor the ancestors were to be blamed for her HIV condition, one can presume that her religious beliefs had prevented her from disclosing her status at an early stage. The fact that she cried during the interview indicates that the matter was still emotionally distressing three years after the first disclosure. The interview reveals both the obstacles to disclosure and the possibility of overcoming them with the emotional support offered by the HIV/AIDS support group.

Another example of a disclosure prompted by the interview situation is Godfrey's story. His interview documents the feelings and emotions of a white person living with HIV/AIDS, an experience that is rarely spoken about in South Africa. Ntokozo Zitha noted an atmosphere of sadness in the interview. He himself spoke of weariness. The key moment was when he spoke of his rejection by a former school friend and of the patronising attitude of fellow worshippers:

I shall tell you about my experience. I grew up in an Afrikaans-speaking community but now I speak English much better. I went to an Afrikaans school and all my school friends were Afrikaners, and kept up with them

57 In AIDS, Intimacy and Care in Rural KwaZulu-Natal (Amsterdam: Amsterdam University Press, 2011) Patricia Henderson makes similar observations on the ability to cope with disease and death in AIDS-stricken rural KwaZulu-Natal. 
over the years. I did come down and visit. As a family we lived in P. and I used to visit quite often on my way up and down on business trips to South Africa, visit my family and so on. I made a mistake one day of telling them that I was HIV positive. My best school buddy never spoke to me again. It has been five years now and that hurts. So I am a bit weary. [... ] When people in this congregation talk about HIV it is about when whites who are sort of privileged help these unfortunate blacks. It is in our power to give to orphanages, to the less fortunate. We give you food, we give you a bit of financial support, what we can, but do not ask us to come into your homes and share with you, pray with you and things like that. [...] We are too respectable to get mixed up. We are not dirt. We do not fall sick of HIV. It does not happen to us. You see what I mean.

\section{A New Found Assertiveness}

Despite their pain and anger the dominant trait of the interviewees was their assertiveness. Previous studies show how people living with HIV/AIDS, especially women, suffer from being blamed for bringing the disease to the community. ${ }^{58}$ But there is another side to this story of stigmatisation and victimisation. The respondents showed a surprising ability to counter the accusations thrown at them by spouses, relatives and community members. They knew that these allegations were unfounded and were able to distance themselves from them. The interviews revealed the irritation or, more accurately, the anger that the attitude of men towards women in matters of sexuality and disease provoked in women. Nokwazi's story was a good example. To her HIV disclosure was a good thing, but she would not disclose her status to men: 'Men are strong-headed. They are just dogs. [...] Even when a man has to give you money he takes it from your pocket. The woman just takes the wallet out and gives him money. All we do as women is in the open, but men are so secretive.'

Part of the Fountain of Life members' resilience came from the knowledge of HIV/AIDS they had gained in the support group and in the ARV clinics they attended. They were fully aware of the seriousness of their condition: they carried a virus which, if left unchecked, could kill them. But they knew that the antiretroviral treatment worked, at least for the majority of them. Some of them shared traditional beliefs and took part in rituals to the ancestors. But they did not trust the traditional healers in matters of HIV treatment. The picture Posel and Campbell gave of popular representations of HIV/AIDS in Limpopo and KwaZulu-Natal in the mid-2000s was very different. ${ }^{59}$ At that time, the word 'AIDS' could hardly be mentioned and traditional ways of explaining disease, as the result of impurity for example, were in open competition with the biomedical discourse.

All interviewees, although to different degrees, had Christian convictions, a few as members of 'born again' churches. Yet they had no time for the pastors who claimed to heal HIV through prayer. As Nonhlanhla said, those who declare that praying made the virus disappear were 'false prophets'. The traditional healers who collected money from the sick under the pretence of healing them were no better. 'They are gambling with the lives of the people.'

One of the most interesting aspects of the Fountain of Life support group members' newfound assertiveness was their ability to articulate their own religious discourse on their experience as people living with HIV. In contrast to the message conveyed by religious institutions, especially in the early years of the epidemic, of HIV/AIDS as a punishment of God or, in its milder form, as the inevitable consequence of a moral transgression, ${ }^{60}$

\footnotetext{
${ }^{58}$ Leclerc-Madlala, op. cit. (note 36); Campbell et al., 'I Have an Evil Child at My House', op. cit. (note 17).

${ }^{59}$ Posel et al., op. cit. (note 16); Campbell et al., 'I have an Evil Child at My House', op. cit. (note 17).

${ }^{60}$ On the history of the religious representations of HIV/AIDS in Africa, see Philippe Denis, 'HIV, AIDS and religion in sub-Saharan Africa: an historical survey', in Haddad, op. cit. (note 43), 57-77.
} 
the Fountain of Life members refused to take any blame, religious or not, for their HIV condition. Rather they emphasised, when speaking of their religious experience, positive aspects such as love, compassion, reconciliation and forgiveness. Crucially, they put more emphasis on the fact of being still alive - thanks to the ARV treatment whose power they attributed to God - than on being under the threat of death. Many interviewees were able to articulate spiritually and, one may say, theologically their views on God, Jesus, the church and Christian morality in a context profoundly transformed by the widespread availability of ARV treatment.

In response to a question on the effect of HIV on her relationship with God, Mary Khumalo thus described with a great richness of expression the journey which took her from anger to peace of mind. At first she rebelled against God who had 'permitted' her to be infected despite the fact that she 'behaved herself' and avoided 'sleeping around'. Quoting a popular church hymn based on a verse of the prophet Jeremiah she imagined a conversation between herself and God: 'My anger definitely goes to the Creator. He tells me, 'I knew you and I chose you to be mine and I have created you. I have no plans to harm you.' Then I get harmed. Even if it is not you, why let the devil harm me?' 'It was' [she summarised], 'a journey of finding me and finding God and re-defining who God is to me from the stubborn woman, rebellious young woman to learning to humble myself at his feet.'

When asked how she managed to live positively with HIV/AIDS, Bridget brought into the picture the traditional Christian teaching that life and death are in God's hands, but instead of seeing it as an invitation to accept HIV/AIDS passively as the will of God, she interpreted it as saying that people living with HIV were no more at risk of dying young than anybody else. God had the power to let them live as long anybody:

Because when I look at it, it does not mean that if I am HIV-positive tomorrow I will die. Somebody can walk on the road at this very moment and get smashed and die. Nobody knows who will go away. Only God knows that Bridget is going to close her eyes today. No doctor, nobody will tell me, 'You are going to die tomorrow'. I said, no. My God knows it, 'This is your day.'

Nonhlanhla, who had led a turbulent youth, described her journey of recovery as a return to God:

I prayed to God when I was sick, when I lost my husband. God knows where I come from. He knows I come from a rubbish bin that has got worms. I said, 'Please give me a second chance so that I can be a living testimony. What I already do in my life, I want to transmit it to other people's lives.'

The ARVs feature prominently in this oral narrative. To Nonhlanhla they are the expression of God's benevolence: 'I took Christ as my personal Saviour. I took him as my Saviour in these ARV tablets, before I put them in my mouth. When I come from the clinic, I say, "Lord, this is nothing you can do better than these tablets".'

Thandeka, who combined Christian faith and belief in the power of the ancestors, made the point that God should not be blamed for her HIV condition because, thanks to the pills, she was still alive:

I do not blame the ancestors because they are not God. Even God I do not blame him. Why did I have the disease? Why did he not protect me because I praise him? I cannot blame him. I do not blame anyone because I do not even know how I got HIV. I do not blame anybody because God has protected me until now when I am taking my pills. I do not blame the ancestors because they are not God. They do not see that I am taking the treatment. It is only God who knows that I take the treatment because I pray. 
The most articulate of all the interviewees on religious matters was Nonhlanhla. She made a long speech to explain that the ministers of religion who refused to promote condoms in their church were wrong because many born again Christians were infected. They did not trust the power of the Holy Spirit:

They say a child of God does not use condoms and then I say, 'Please, can you show me in the Bible where it is written about condoms?' I used to say at this point that we put the Holy Spirit aside because we all have the Holy Spirit, the one of speaking in tongues, because we speak about the reality of life. [ . . ] I feel sorry for my church because a lot of people have died of AIDS in my church.

Likewise she was adamant that the ARV treatment was wanted by God. If she had the power, she insisted, she would go to Parliament and ask the government to close the churches who speak against the treatment.

They say that if you are a child of God, you do not take the treatment and I will say: Can you please page for me in the Bible and show me where that is written. Jehovah is not against the treatment because if he was, we would not have the doctors, the scientists and all those who have a hand in discovering the treatment, and those who diagnose people who have diseases.

\section{Conclusion}

In their paper on sex, disease and stigma in South Africa, Delius and Glaser began by saying, on the basis of two studies published two years earlier, ${ }^{61}$ that 'in South Africa infected individuals have been shunned, abandoned, isolated, expelled and even killed by horrified neighbours and kin'. Further they added: 'More recent surveys have, however, presented a much more sanguine view suggesting that levels of stigma are relatively low. ${ }^{62}$ This indicates that as early as in 2005, when Delius and Glaser wrote their paper, the perception already existed that the reality of stigma was changing. A similar point was made by Simbayi and his colleagues in $2007,{ }^{63}$ and by Visser and Sipsma in 2013 on the basis of a study conducted between 2003 and 2006. ${ }^{64}$ But if stigma has changed, we can ask: by how much and how fast?

The ten oral history interviews we have examined do not give a firm answer to the question of whether it has become easier to disclose one's HIV status a decade after ARVs have been made widely available in the South African public health system. The sample only includes support group members who are expected to have already disclosed - or started to disclose - their HIV status anyway and in any case it is too small to claim representativeness. It does not claim to be representative. The material discussed here allows us, however, to make a certain number of observations.

All ten interviewees were on ARVs. A requirement for starting a treatment is to attend up to three sessions of counselling and patient education of about half a day each. From that point of view our research participants were no different from the two million HIV-positive people who have started - and will hopefully continue - ARV treatment in South Africa since 2004, and of the millions of people who took part in the mass HIV counselling and testing campaign launched by the South African government in April 2010. With countless sessions of counselling and patient education coupled to monthly visits to the clinic and a bi-annual encounter with a medical doctor, one can expect that the level of HIV education has increased in the general population. This does not mean that stigma has disappeared

${ }^{61}$ Stadler, op. cit. (note 11); Jo Stein, op. cit. (note 12).

62 Delius and Glaser, op. cit. (note 1), 29.

63 Simbayi et al., 'Internalized AIDS Stigma', op. cit. (note 10), 1824.

64 Visser and Sipsma, op. cit. (note 24), 12-13. 
or that the confusion created by competing world-views and belief systems has dissipated. Yet the situation of extreme denial and ideological confusion observed, for example, by Deborah Posel and her colleagues in 2003 and 2004 in Agincourt or by Isak Niehaus in Bushbuckridge in 2007 seems to have lessened.

Not one of the ten support group members interviewed for this study, half of whom came from a poor educational and socio-economic background, showed confusion regarding the causes of HIV/AIDS and the effectiveness of the ARV treatment. All were able to distinguish between the 'pills', that is, a medication preventing the health condition of HIV-positive people from deteriorating, the power of God, and the role played by the ancestors. Some combined these three belief systems, saying for example that God wanted the ARVs to work, but none played one against the others. On the contrary, they blamed the traditional healers and preachers of healing churches who claimed more success that the ARV treatment. For them the cause of the disease was a physical reality - the HIV virus - and not a human or spiritual agency - ancestors, evil spirits, malicious neighbours or the Christian God - as postulated in traditional health systems.

The most important finding of this study, one that only a qualitative study can bring to light, is what I call here the new-found assertiveness of people living with HIV. On all the subjects on which the research assistant asked them to speak - and with the help of the topic guide she used for the interviews - they spoke with confidence. One of the six factors of stigma Catherine Campbell and her colleagues highlighted in their study was the lack of social spaces to talk about HIV/AIDS. ${ }^{65}$ This did not apply to the Fountain of Life support group members. For them it was not only a matter of medical knowledge. All of them, in different ways, were able to talk about sensitive and painful issues. They used the resources of their Christian religion and, for some of them, also of African traditional religion to give a spiritual meaning to their experience without falling into the trap of church-induced self-blame and denial. They did not hesitate to distance themselves from their church leaders when necessary.

All interviewees, with perhaps one exception, had experienced stigma and discrimination. Because most of them had tested HIV-positive eight years or more before the interview, these negative experiences did not necessarily concern recent periods. In fact most of them dated from the time of their first disclosure in the late 1990s or early 2000s. One cannot say, therefore from that point of view, that the interviews document a decrease in stigma and discrimination.

What the interviews do document however is twofold. First, they hint at the possibility that people living with HIV may have had, more than in the early stages of the epidemic, a language to express the emotions and feelings associated with HIV/AIDS. That would have made disclosure easier and stigma more likely to recede. The support group members developed, to quote Foucault's phrase, 'technologies of the self' which allowed them to express the multi-layered and sometimes contradictory aspects of their experience of HIV. Some of them used the language of religion to justify and advocate for the use of antiretrovirals. They could have said, like the Treatment Action Campaign activists interviewed by Steve Robins in 2004 in the Eastern Cape, that HIV was a 'blessing in disguise'. ${ }^{66}$ By promoting HIV awareness, care, treatment and support among their peers and in their communities and producing a well-articulated discourse on HIV/AIDS

65 Campbell et al., 'Dying twice', op. cit. (note 17).

${ }^{66}$ Robins, op. cit. (note 5), 316-18. 
they contributed to the development of what some authors have described as 'biological', 'responsibilised' or 'therapeutic' citizenship. ${ }^{67}$

It is, of course, perilous to generalise this observation which is based on the testimonies of members of a well-structured HIV/AIDS support group that receives assistance from local NGOs. One would have to see if similar changes are observed among members of less structured support groups in peri-urban or rural areas. A question to ask is whether the ability to articulate the emotions associated with HIV/AIDS is part of a new culture that encourages people to be more open about their emotions. On the other hand, one could argue that it is the forums and support groups generated by the HIV/AIDS epidemic that have contributed to the development of this culture. ${ }^{68}$

The second finding, which in a sense contradicts the first, is the persistence of the stereotype of the 'loose woman' who 'sleeps around' and infects husbands and lovers. The fear of being stigmatised for that reason makes women less prone to disclose their HIV status, especially to men. It encourages an atmosphere of anxiety and suspicion.

If sex-related cultural taboos were part of the Fountain of Live support group members' world-view as they were in Agincourt, they did not find expression in the interviews. What appeared rather was the anger of women against men, accused of being domineering, stubborn and unable to handle the risk of HIV infection responsibly. It is this message which came out the most clearly in the interviews. As one of them said, 'men are like dogs'. If stigma persists, according to the women interviewed, it is because of the attitude of men. The 'men bashing' discourse documented in the interviews is indicative of a remarkably high level of gender awareness.

This is only a preliminary report, and the conclusions tentative. More material has to be collected and analysed, in particular from men infected or affected by HIV/AIDS in KwaZulu-Natal. As the epidemic enters its fourth decade, it becomes increasingly clear that it is accompanied by profound changes in matters of gender, beliefs and interpersonal relationships.

${ }^{67}$ Respectively Adriana Petryna, Life Exposed: Biological Citizens after Chernobyl (Princeton, NJ: Princeton University Press, 2002); Robins, op. cit. (note 5), 314; Nguyen, op. cit. (note 4), 108-9.

${ }^{68}$ I owe these insights to Julie Parle. 